\title{
Assessment of Shallow Groundwater Quality for Irrigation in parts of Agra District, Uttar Pradesh, India
}

\author{
P. K. Singh ${ }^{1}$, S. Atal ${ }^{2}$ and S. K. Dubey ${ }^{3}$ \\ ${ }^{1}$ Geological Survey of India, Itanagar \\ 2 Geological Survey of India, Jaipur \\ ${ }^{3}$ CSWCRTI, Chhalesar, Agra \\ Email: pk_gsi@yahoo.co.in
}

\begin{abstract}
Study of physiochemical properties of groundwater in an area of $1000 \mathrm{sq} \mathrm{km}$ around Agra city, Uttar Pradesh, India was carried out to decipher the suitability of groundwater for irrigation. About $78 \%$ of the study area is utilized for agriculture and most of the crops are irrigated with tubewells (i.e. from groundwater sources). Therefore, it is important to study the quality and suitability of the groundwater for this purpose. Since the area falls under the Semi-arid zone, the average frequency of irrigation is high for the crops being harvested, the proper soil management is needed for sustainable agricultural development of the area.
\end{abstract}

A total of 200 groundwater samples were collected (pre- and post-monsoon) from hand pumps, submersible pumps, and irrigation tubewells as per the availability on a grid pattern between the periods of June 2012 to February 2014. The samples were analyzed for major, traces and other physical properties of the water like $\mathrm{pH}$, TDS, and electrical conductivity. To evaluate the quality of the groundwater different irrigational parameters like Electrical Conductivity (EC), Kelly's Ratio, Sodium Adsorption Ratio (SAR) values, Magnesium Adsorption Ratio and Sodium Percentage were worked out. Wilcox diagram indicates that $18 \%$ of water samples fall in unsuitable class while $14 \%$ samples are in Doubtful to Unsuitable class while about $47 \%$ of samples are good to permissible for irrigation. USSL diagram shows that the majority of the samples fall in S1C3 (50.5\%) and S2C4 (20.3\%) and only 2.3\% samples are falling in S1C2 Class with low alkali and medium salinity hazard. Therefore, the majority of the water sources are either unsuitable for irrigation or may be used with adequate management of drainage and salinity treatments. The Magnesium Adsorption Ration of the samples is even worse and more than $90 \%$ samples are failing this parameter for irrigation. 51\% samples are showing Kelly's ratio of $>1$, failing to qualify the standard for irrigation water. Doneen's plot indicates that $39.3 \%$ of water samples are falling in Class-III field with $<25 \%$ maximum permeability which is not suitable for irrigation in normal conditions.

Keywords: Groundwater quality, Irrigation, Sodium Absorption Ratio (SAR), Kelly's Ratio, Wilcox diagram, USSL diagram, Agra 


\section{INTRODUCTION}

Groundwater is an inevitable resource for the sustainable agricultural development of an area. The alluvial plains of Yamuna River system are very fertile and sustain intensive agriculture. Groundwater is the prime source of irrigation with the development of a series of tubewells and discontinued use of irrigation canals due to improper management and discontinuous supply of water in the area. The quality of groundwater is a very important factor for the irrigated agriculture and the soil fertility. Therefore, groundwater quality study was carried out in an area covering about $1000 \mathrm{sq} \mathrm{km}$ around Agra city, Uttar Pradesh with an objective to evaluate the suitability of the groundwater for various purposes. This study is oriented to evaluate the irrigational utility groundwater for agricultural purpose.

The present study is carried out in the area around Agra city in the Yamuna river basin. (Fig.1). It falls in the semi-arid zone of climatic class. The summers are very hot with maximum temperature shooting up to $48^{\circ} \mathrm{C}$ in the month of June whereas the winters are mild to very cold with minimum temperature dipping up to $23^{\circ} \mathrm{C}$ during the months of December and January.
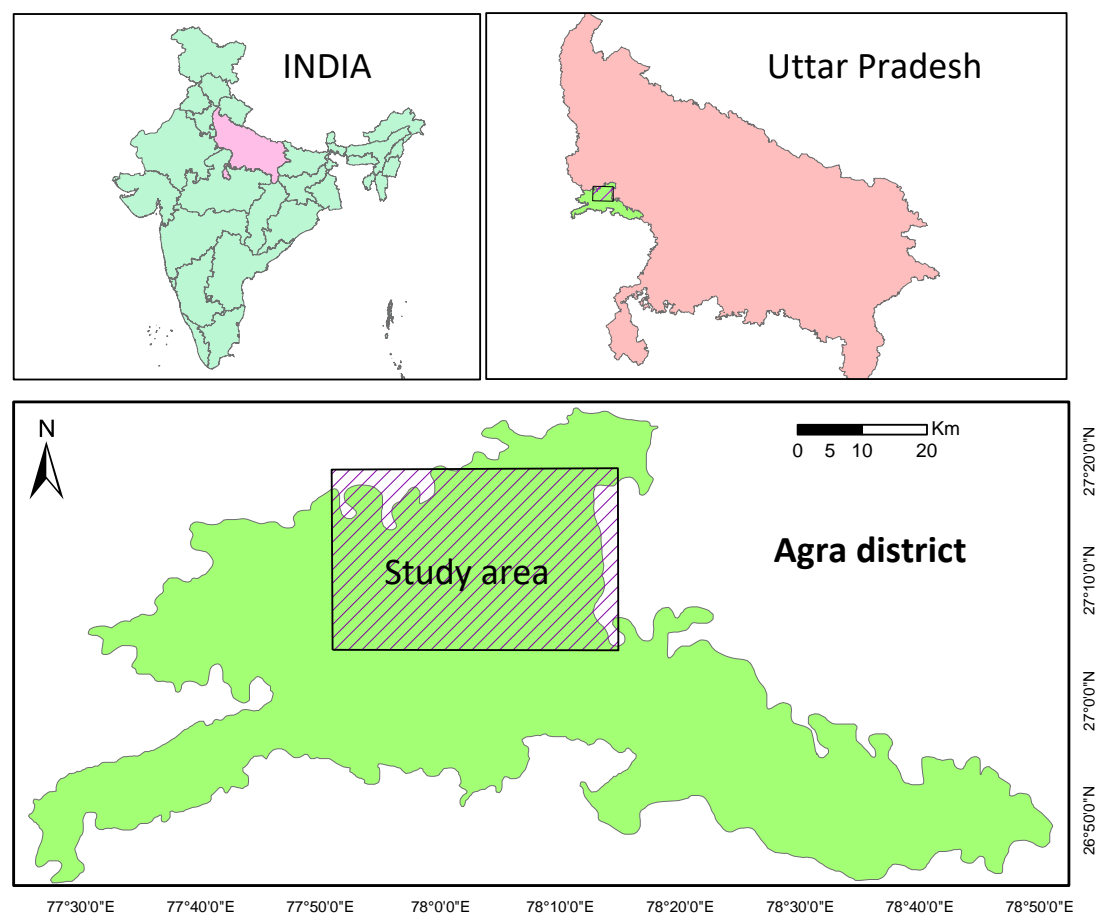

Fig.1: Location map of the study area.

\section{METHODOLOGY}

Groundwater samples were collected from different sources like hand pumps, submersible pumps and tube wells in clean plastic bottles, preserved as per standard guidelines and analyzed for major ions and trace elements. The sampling was done on a grid pattern with the availability of the samples (Fig.2). The analytical results are used to evaluate the quality of the groundwater in the area for irrigation purpose. The plotting the data derived for different parameters were contoured with the help of Surfer-12 software applying kriging Interpolation. The land use map was prepared using recent Google Earth map followed by field checks. The samples were analyzed at the Chemical Laboratory of Geological Survey of India, Lucknow (U.P.) using 
Assessment of Shallow Groundwater Quality for Irrigation in parts of Agra District, Uttar Pradesh (India): Singh et al.

standard methods. The concentrations were provided in $\mathrm{mg} / \mathrm{l}$ which was recalculated into meq/l. The various parameters like Sodium Adsorption Ratio, Sodium Percentage, Magnesium Adsorption Ratio, Permeability Index, Residual Sodium Carbonate and Kelly's Ratio were calculated using standard formulae. Ultimately for classifying water into suitability classes, Wilcox diagram, USSL diagram, and Doneen's plot were prepared for and results were interpreted.

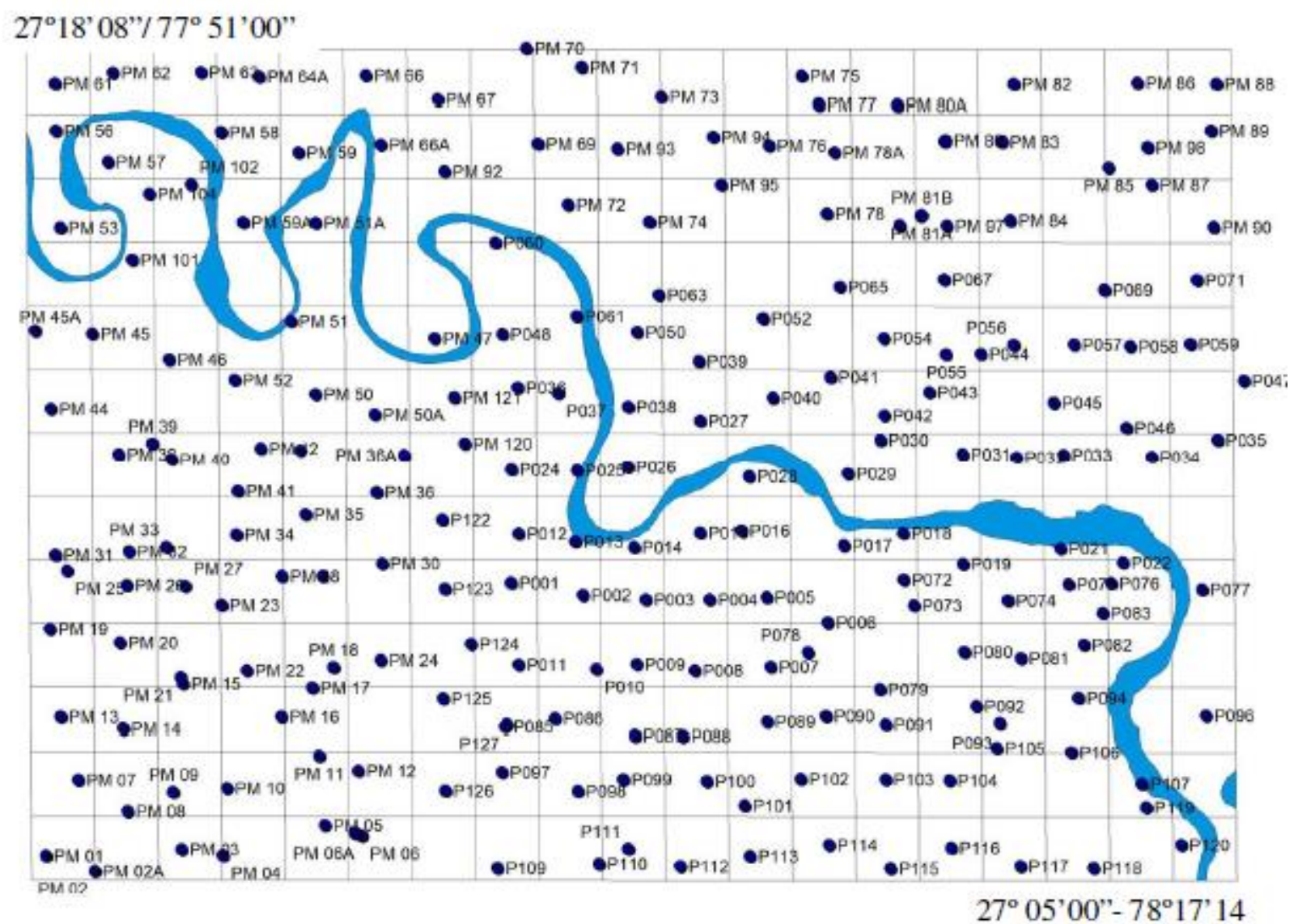

Fig.2: Sample location map of the area around Agra.

\section{STUDY AREA}

\section{Geology:}

Geologically, the area comprises sandy to silty-clay with kankar horizons at different levels classified under Varanasi Alluvium, locally called Agra Alluvium (Older Alluvium) of Middle to Late Pleistocene age (Fig.3). The Older Flood Plain (Terrace deposits) and Newer Flood Plain deposits, comprising active channels, sand bars, and pits are grouped under Newer Alluvium of Holocene age. Most of the part of the study area is covered by Varanasi Older Alluvium. Two types of nodules are recorded around Netpura village, to the southwest of Agra (Singh and Atal, 2014). Vindhayan rocks (Upper Bhander ferruginous Sandstone) are exposed around $25 \mathrm{~km}$ away towards the south-west of the area. 


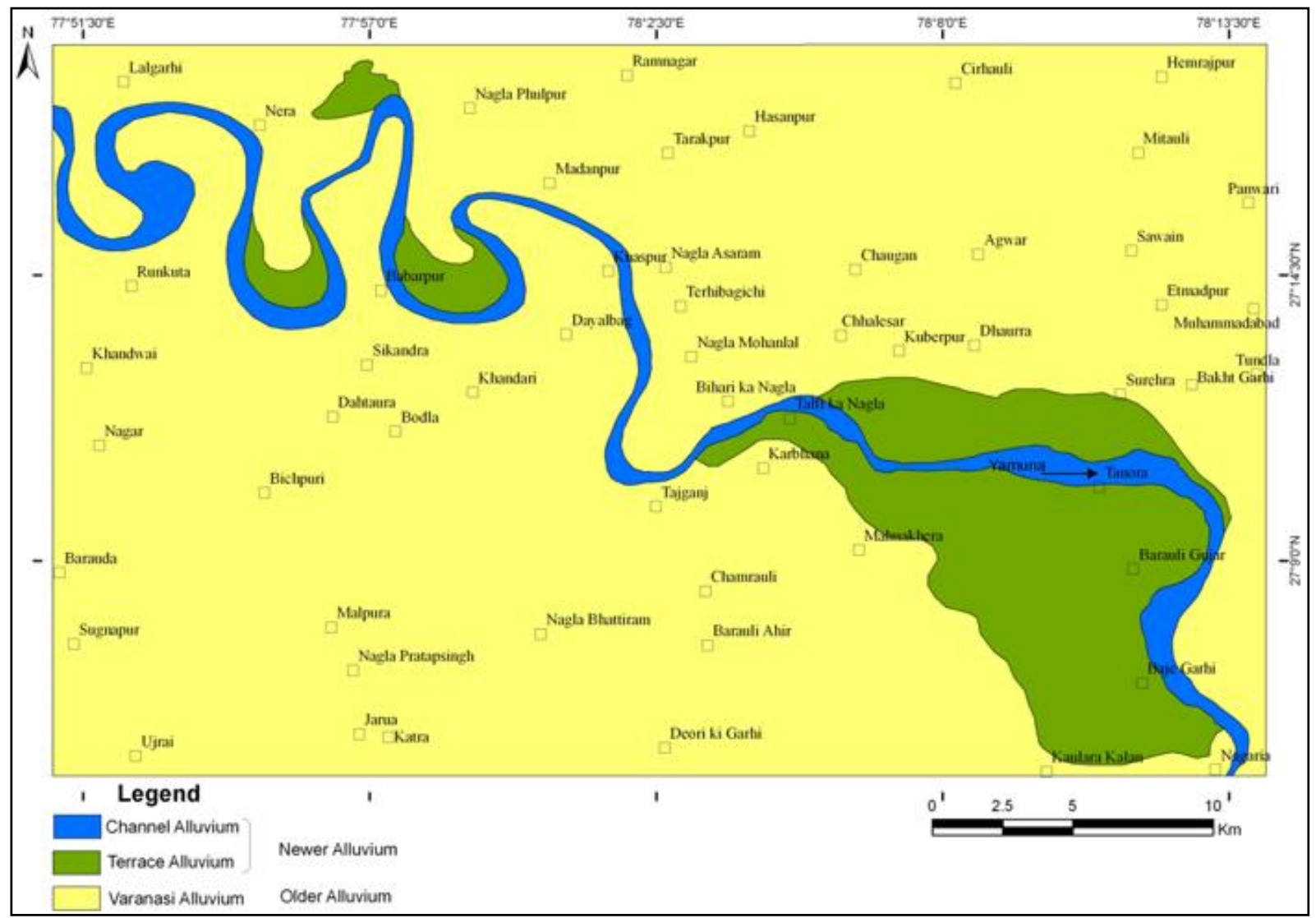

Fig.3: Geological map of the area around Agra.

\section{Geomorphology:}

Geomorphologically, the area has been divided into Older Alluvial Plain, Older Flood Plains and Active Flood Plain (Newer Flood Plain) of the Yamuna and its tributaries. A major part of the area is covered by the Older Alluvial Plain (Varanasi Alluvial Plain) which is a very gently sloping plain, mostly used for agricultural and settlement activities.

The Yamuna, Chambal, and their tributaries constitute the major drainage system of the area. Uttangan River joins the Yamuna around Bah. The general slope of the area is towards the south-east. Most of the streams are $1^{\text {st }}$ or $2^{\text {nd }}$ order debouching into the Yamuna River. These tributaries are rain fed and get dry during summers. Due to imprudent planning, many of these streams have been converted into sewer lines in the city carrying the sewage into the Yamuna River. Patches of highly rugged badland, resulted due to intensive gully erosion of the Older Alluvium, covered with dense babool and thick grasses are recorded along the Yamuna and its tributaries. The general physiographic slope of the area is towards east and the Vindhyan rocks are exposed to the south-west of the area (Fig.4). 


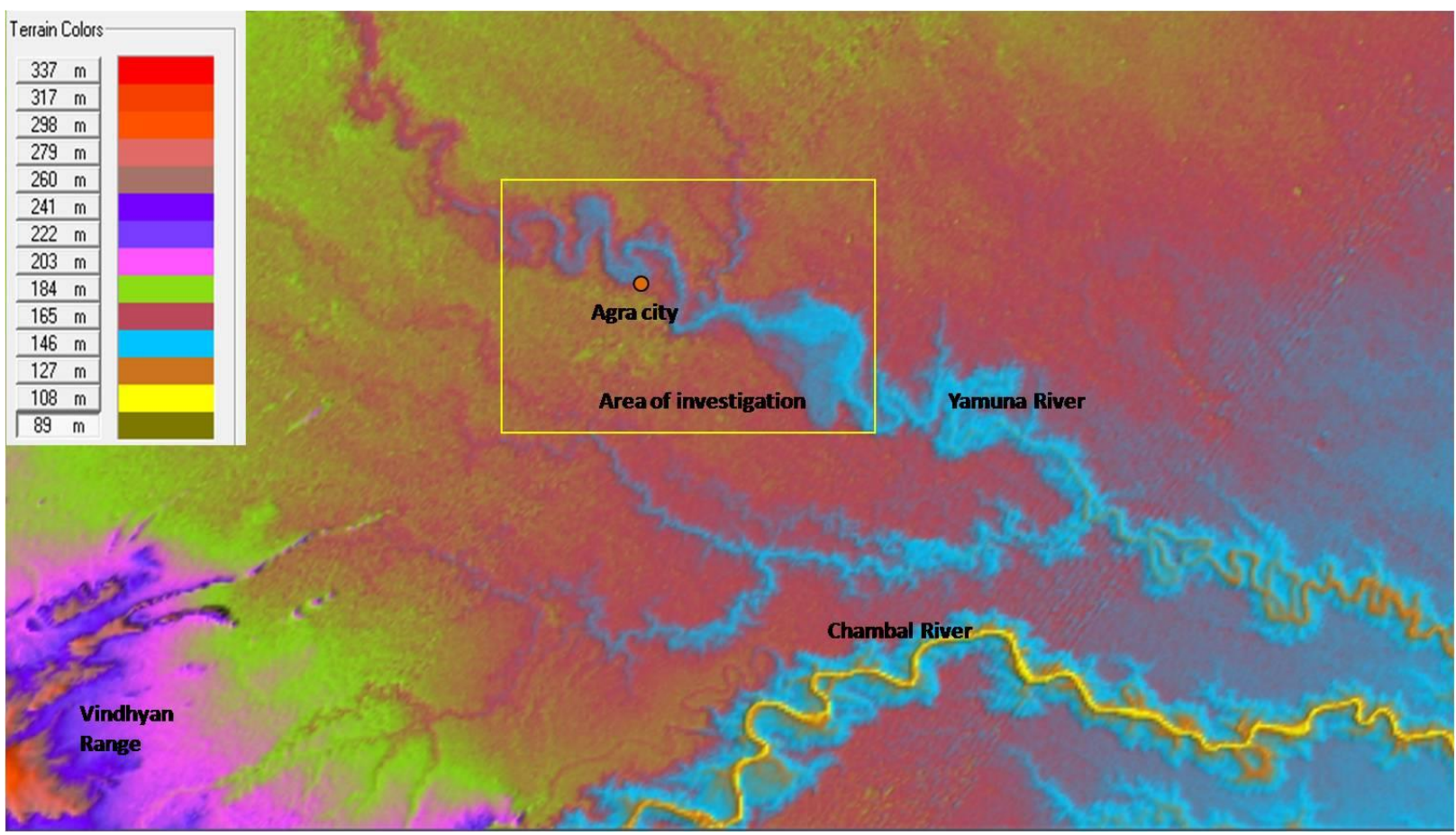

Fig.4: Digital Elevation Model of the area showing general Physiography (SRTM 30m).

\section{Hydrology:}

The Yamuna River is effluent in nature except during monsoon seasons. The groundwater in Yamuna Basin occurs under unconfined, semi-confined and confined conditions. In general, groundwater movement is from south-west to north-east on the right bank and north-east to southwest on the left bank (Rai, 1996). The population of Agra district mainly depends on hand pumps (both India mark II and private) and submersible pumps to fulfill their domestic needs. The government hand pumps (India Mark-II), as well as private hand pumps, are installed at a depth between $20 \mathrm{~m}$ to $30 \mathrm{~m}$ however the submersible tube wells are installed at a depth of $50-80 \mathrm{~m}$. The recorded seasonal fluctuation of water level ranges from 0.2 to $7.2 \mathrm{~m}$ (State Ground Water Department, 2012). The long-term water level trend of permanent hydrograph stations fixed by State Groundwater Department shows a declining trend of water level in general, however, at places, the local rise has also been noticed.

\section{Land use and Cropping pattern:}

The area around investigation includes the urban agglomeration of the Agra-Sikandara city and the adjoining rural-urban fringe along with the villages surrounding the city. About $78 \%$ of the area is utilized for agricultural purposes (Fig. 5,6). The major crops are potato during the winter seasons along with wheat, paddy, and vegetables. The cropping pattern changed in the last few decades due to the change in the irrigation facility. The urban settlement covers about $12 \%$ of the area followed by rural settlement by about $4 \%$ (Singh and Atal, 2014). 


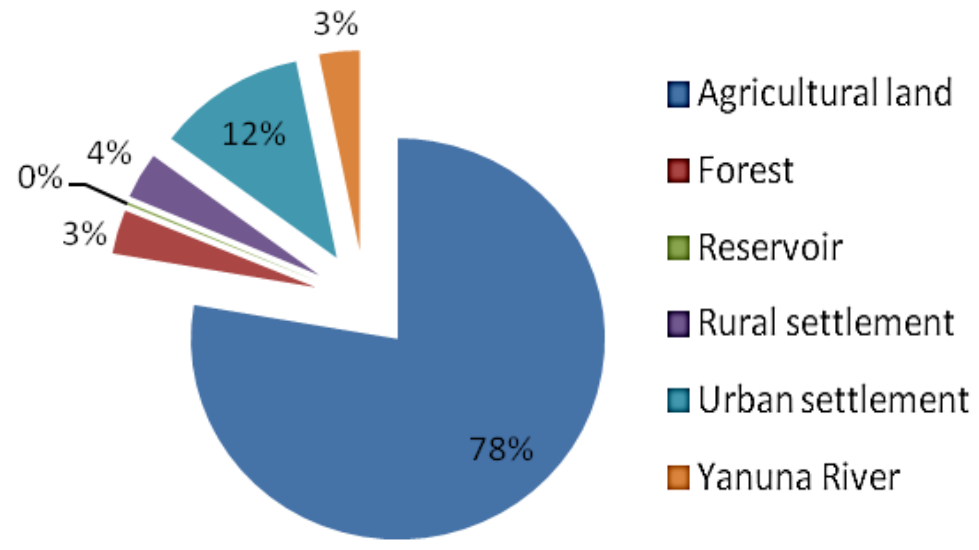

Fig.5: Land use pattern of the area.

The intensive multiple cropping of wheat, millet, potato, mustard, paddy and pigeon pea along with vegetables and fruits is the specialty of the area. $90.4 \%$ of the irrigation is done by bore wells (government and private pumps) followed by $9.5 \%$ by canals and $0.1 \%$ by open wells in Agra district (Ministry of Agriculture, Gol) facilitating $135 \%$ of cropping intensity in the district.

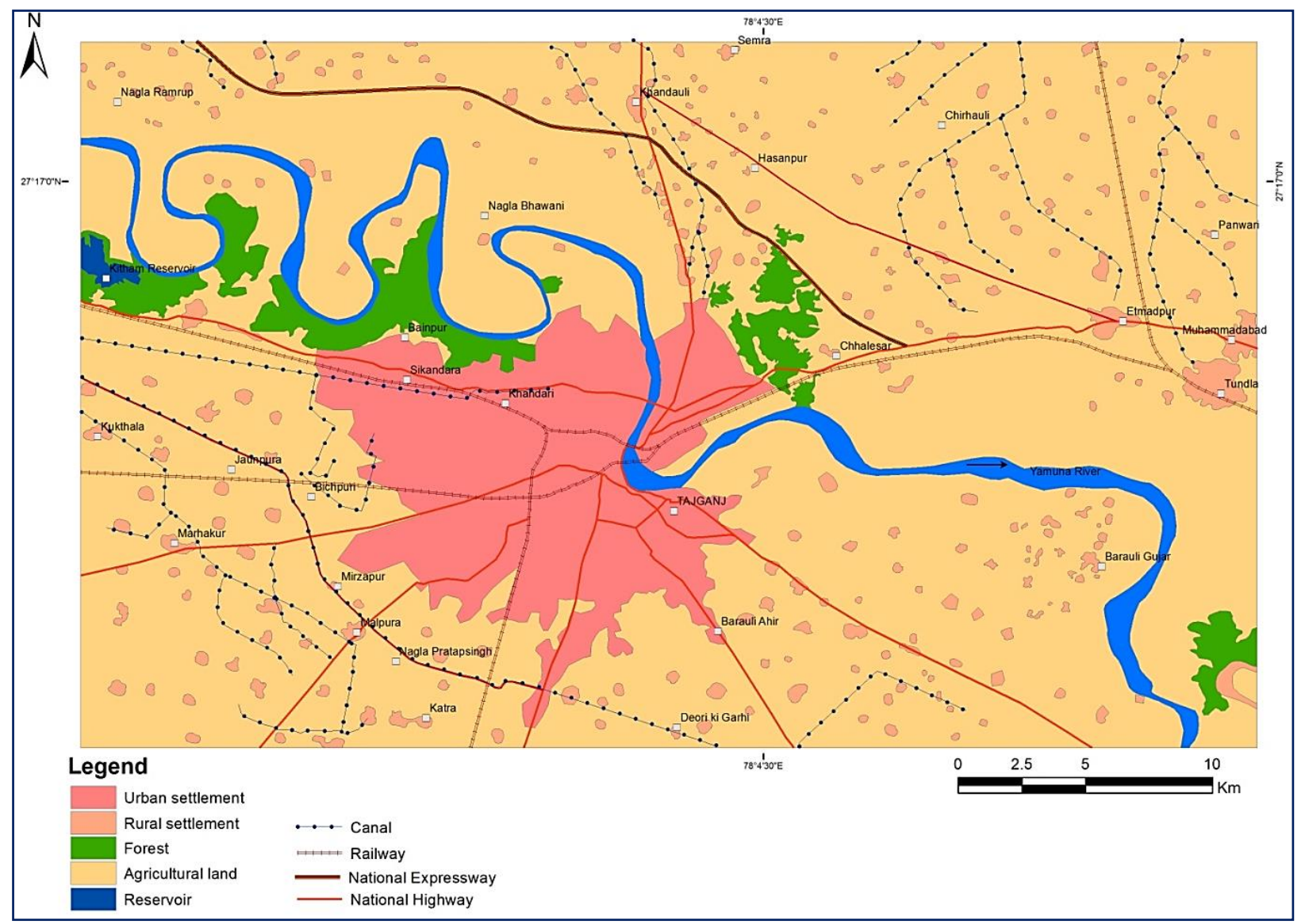

Fig.6: Land use map of the area around Agra city. 


\section{ASSESSMENT OF WATER QUALITY FOR IRRIGATION}

Suitability of the groundwater for irrigation depends on the effects of mineral constituents present in the irrigation water on the soil and the plants grown. Salts may directly harm the plants physically by limiting the intake of water or by changing their metabolic rate. The salts affect the permeability, structure, and aeration of the soil, thus indirectly affecting the crops. The suitability of the water for irrigation depends on many factors including soil type, drainage characteristics, salt tolerance of the plants and climate of the area (Michael, 1990). Different Indices have been derived and being used the world over for evaluation of the water quality for irrigation (Raghunath, 1987; Todd, 1995; Quddus and Zaman, 1996; Talukder et al., 1998; Sarkar and Hassan, 2006; Raihan and Alam, 2008). Sodium concentration is an important factor in all the Indices in classifying irrigation water because sodium reacts with soil to reduce its permeability (Todd, 1995). The Electrical conductivity (EC), Sodium Adsorption Ratio (SAR), Sodium percentage, Residual Sodium Carbonate (RSC), Magnesium Adsorption Ratio (MAR), Permeability index (PI) and Kelly's Ratio are considered as the most important indices to determine the suitability of the water for irrigation purposes (Khan et al., 2013).

\section{Electrical Conductivity (EC):}

The electrical conductivity of water is the function of total ionic concentration thus related to the TDS of the water. EC is an important parameter to measure the salinity hazard due to irrigation. Electrical conductance in the analyzed groundwater samples varies from 565 to 16440 micro mho/cm measured at $25^{\circ} \mathrm{C}$ with an average of $2902 \mathrm{micro} \mathrm{mho} / \mathrm{cm}$. Highest values of EC is recorded to the NE of Sikandara (Fig.7). On the basis of Wilcox's classification of water based on specific conductance, it is found that more than a quarter $(28.9 \%)$ of the groundwater sources in the area around Agra city are unsuitable for irrigation and only $2.6 \%$ of samples are found to be good for the purpose (Table-1).

Table-1: Classification of Groundwater for Irrigation on the basis of Electrical Conductivity (After Wilcox, 1955)

\begin{tabular}{|l|l|l|l|l|}
\hline $\begin{array}{l}\text { Water } \\
\text { Class }\end{array}$ & $\begin{array}{l}\text { Electrical conductivity } \\
\text { (micromho/cm at 25-C) }\end{array}$ & \multicolumn{3}{|c|}{ Percentage of samples (\%) } \\
\hline & & $\begin{array}{l}\text { Pre-monsoon } \\
(182 \text { samples })\end{array}$ & $\begin{array}{l}\text { Post monsoon } \\
(198 \text { samples })\end{array}$ & Total \% \\
\hline Excellent & $<250$ & 0 & 0 & 0 \\
\hline Good & $250-750$ & 2.2 & 3 & 2.6 \\
\hline Permissible & $>750-2000$ & 61 & 50 & 55.3 \\
\hline Doubtful & $>2000-3000$ & 12.6 & 13.6 & 13.2 \\
\hline Unsuitable & $>3000$ & 24.2 & 33.3 & 28.9 \\
\hline
\end{tabular}




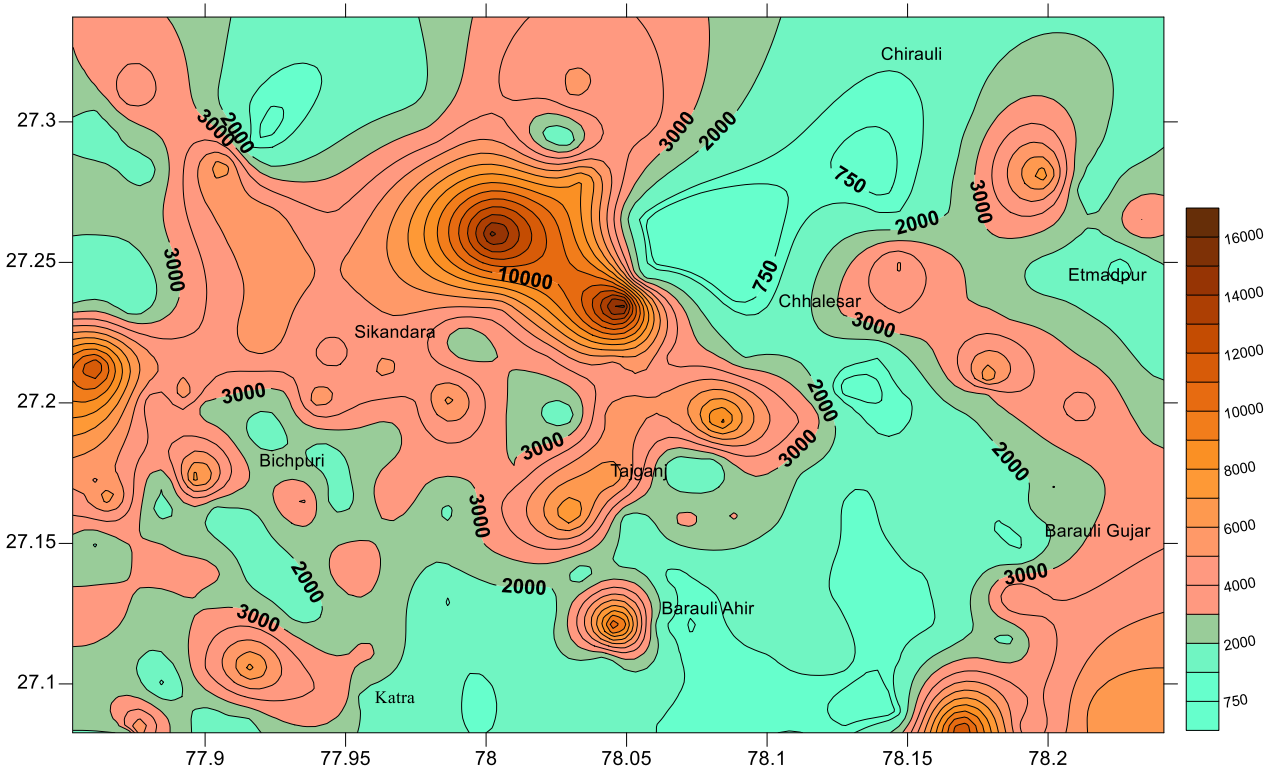

Fig.7: Electrical Conductivity contour map.

\section{Kelly's Ratio:}

Kelly's ratio is considered as an effective index to assess the suitability of water for irrigation (Kelly, 1951). The ratio of sodium versus calcium and magnesium is known as Kelly's ratio (Kelly, 1963). The water with Kelly's ratio of more than 1 is considered unsuitable for irrigation. The Kelly's ratio for pre-monsoon samples varied from 0.09 to 6.5 whereas for post monsoon samples it ranges from 0.01 to as high as 10.6. Highest values are recorded from the western part of the area to the NW and SW of Sikandara (Fig.8). Therefore, it indicates that most of the water sources are unsuitable for irrigation use on the basis of Kelly's ratio.

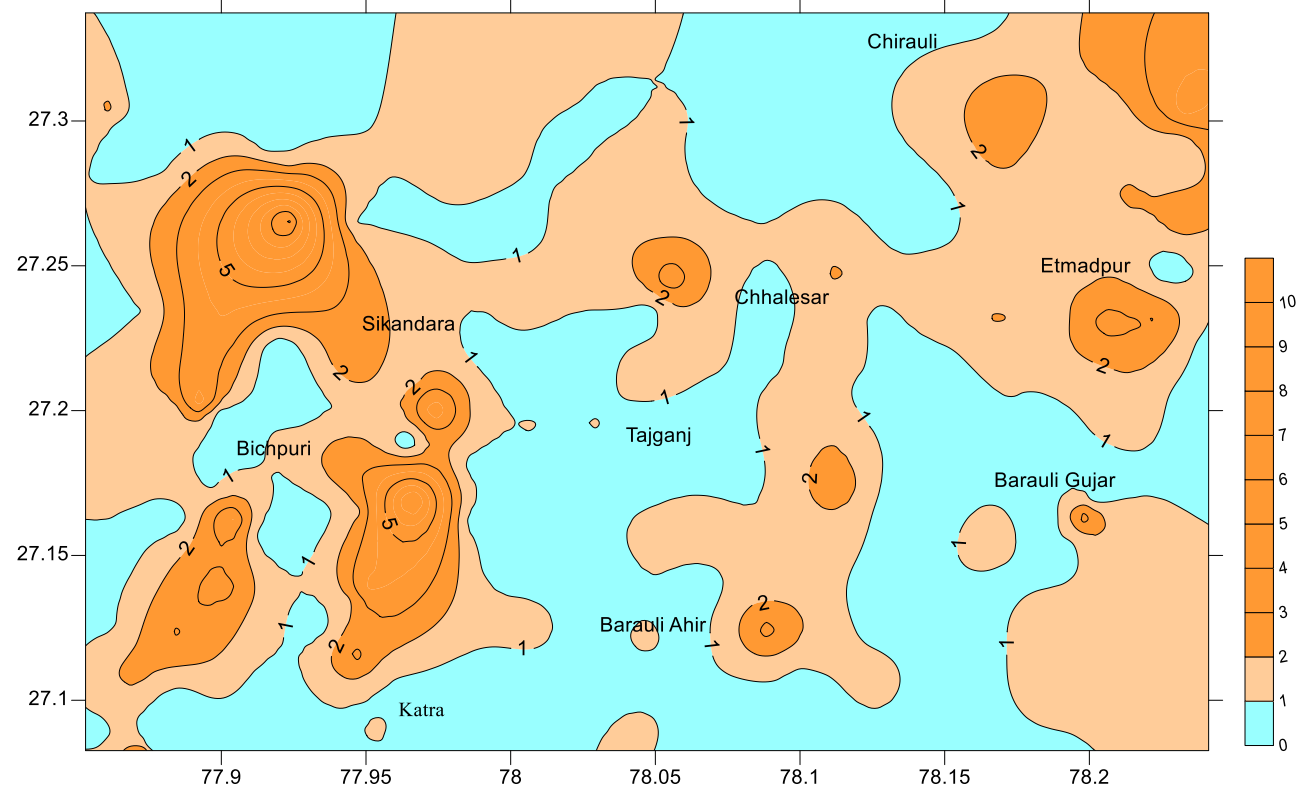

Fig.8: Classification of groundwater on the basis of Kelly's ratio. 


\section{Magnesium Adsorption Ratio (MAR):}

Magnesium adsorption ratio is one of the most important qualitative criteria for evaluating the quality of water for irrigation (Obiefuna and Sheriff, 2011). In general, calcium and magnesium should be in the state of equilibrium in water for irrigational use. High concentration of magnesium in water makes the water saline and adversely affects the yield of the crops (Joshi et al., 2009). The Magnesium Adsorption Ratio is expressed as the ratio of $\mathrm{Mg}$ and $\mathrm{Ca}+\mathrm{Mg}$ in percentage.

Water with MAR over 50 is considered unsuitable for irrigation purpose. In all the samples the Magnesium Adsorption Ratio ranges from 22 to 98 for Pre-monsoon samples and 28 to 98 for post-monsoon groundwater samples. About $97 \%$ of the pre-monsoon samples and $91 \%$ of postmonsoon water samples are showing $>50 \mathrm{MAR}$ indicating almost all the groundwater is unsuitable for irrigation on the basis of this criteria.

\section{Permeability Index:}

Irrigation accumulates the salts in the soil with time but the proper drainage controls the rate of accumulation of salts. When the water is rich in dissolved salts it adds the salts on a faster pace. These salts affect the permeability of the soil in long term. Presence of high calcium, sodium, bicarbonate, and magnesium influence the permeability the most (Chandu et al., 1995). If water has excess sodium it is absorbed by the soil and permeability of the soil is reduced (Ayers and Bronson, 1975). Permeability Index is used to evaluate the quality of water for irrigation in long consistent use.

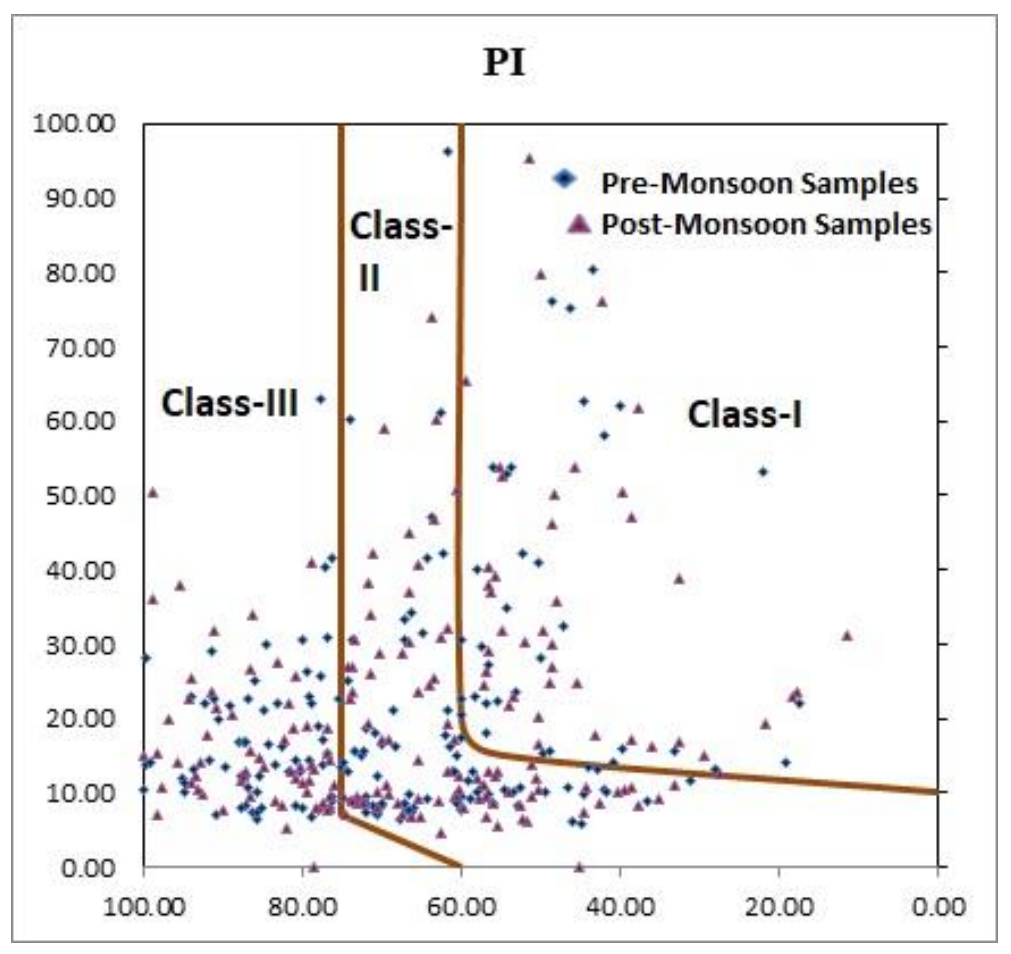

Fig. 9: Doneen's Plot for Groundwater samples of Agra for Irrigation Quality Classification.

Water samples falling under Class I and II with $75 \%$ or more of maximum permeability are suitable for irrigation while the Class III samples with $25 \%$ permeability are unsuitable for irrigation (Table-2) (Doneen, 1961; Domenico and Schwartz, 1990). 

et al.

On the basis of Doneen's diagram for classification of water for irrigation, $20.2 \%$ samples are falling in Class-I and $40.5 \%$ in Class-II which are considered as suitable for irrigation but the water samples falling in Class-III constitute $39.3 \%$ of total samples which are not suitable for irrigation (Fig.9).

Table-2: Classification of groundwater samples on the basis of Doneen's plot

\begin{tabular}{|c|c|c|c|c|}
\hline \multirow{2}{*}{$\begin{array}{l}\text { Type of } \\
\text { water }\end{array}$} & \multirow{2}{*}{$\begin{array}{l}\text { Maximum } \\
\text { Permeability }\end{array}$} & \multicolumn{2}{|c|}{ No. of samples } & \multirow{2}{*}{$\begin{array}{l}\text { Average } \% \text { of } \\
\text { samples }\end{array}$} \\
\hline & & Pre-monsoon & Post monsoon & \\
\hline Class I & $>75 \%$ & 34 & 43 & 20.2 \\
\hline Class II & $25-75 \%$ & 68 & 86 & 40.5 \\
\hline Class III & $<25 \%$ & 80 & 69 & 39.3 \\
\hline
\end{tabular}

\section{Residual Sodium Carbonate:}

Hazardous effect of carbonate and bicarbonate in the irrigation water can be determined using the Residual Sodium Carbonate (RSC) parameter (Eton, 1950). In clayey soil, the high RSC leads to swelling of soil and delimiting the filtration capacity of the soil. Irrigation of clayey soil for a long time with high RSC water may result into alkali soil formation.

A high proportion of carbonate and bicarbonate in relation to the available calcium and magnesium precipitates $\mathrm{Ca}$ and $\mathrm{Mg}$ as carbonates and thus water becomes rich in sodium which decreases the soil permeability. The pre-monsoon samples show RSC values from -42.1 to as high as 36.9. $42 \%$ samples show RSC values $<1.25 \mathrm{meq} / \mathrm{l}$, therefore they are safe for irrigation whereas $52 \%$ samples are unsuitable due to RSC values $>2.5$ meq/l (Fig.10).

Table- 3: Rating of water on the basis of RSC for irrigation purpose

\begin{tabular}{|l|l|l|}
\hline RSC (meq/l) & Water Class & Percent samples \\
\hline$<\mathbf{1 . 2 5}$ & Safe & $42 \%$ \\
\hline $\mathbf{1 . 2 5}-\mathbf{2 . 5 0}$ & Marginal & $6 \%$ \\
\hline$>\mathbf{2 . 5 0}$ & Unsuitable & $52 \%$ \\
\hline
\end{tabular}

\section{Percent Sodium:}

Sodium content in the irrigation water determines the cation exchange reaction rate of the soil. It is expressed as Percent Sodium (also known as soluble sodium percentage) (Todd, 1995). High concentration of sodium in irrigation water reduces the permeability of the soil and affects the plant growth (Joshi et al., 2009). High sodium in water requires special soil management like good drainage, organic manures addition, and high leaching facilities. As per Wilcox classification of water for irrigation, water with $<20 \% \mathrm{Na}$ are excellent for irrigation whereas between $20-40 \%$ it is good, between $40-60 \%$ it is permissible and between $60-80 \%$ it is doubtful and if $\mathrm{Na} \%$ is $>80$ the water is unsuitable for irrigation. The $\mathrm{Na}$ percent of the pre-monsoon water samples range from $9.8 \%$ to $86.7 \%$ with an average of $52.7 \%$ whereas the sodium percent for post monsoon samples it ranges from $4.8 \%$ to as high as $91.8 \%$, with an average of $49.1 \%$. Total of about $32 \%$ 
Assessment of Shallow Groundwater Quality for Irrigation in parts of Agra District, Uttar Pradesh (India): Singh et al.

of samples is showing more than $60 \%$ of Sodium Percentage indicating about third water samples are doubt to unsuitable for irrigation on the basis of this parameter (Fig.11).

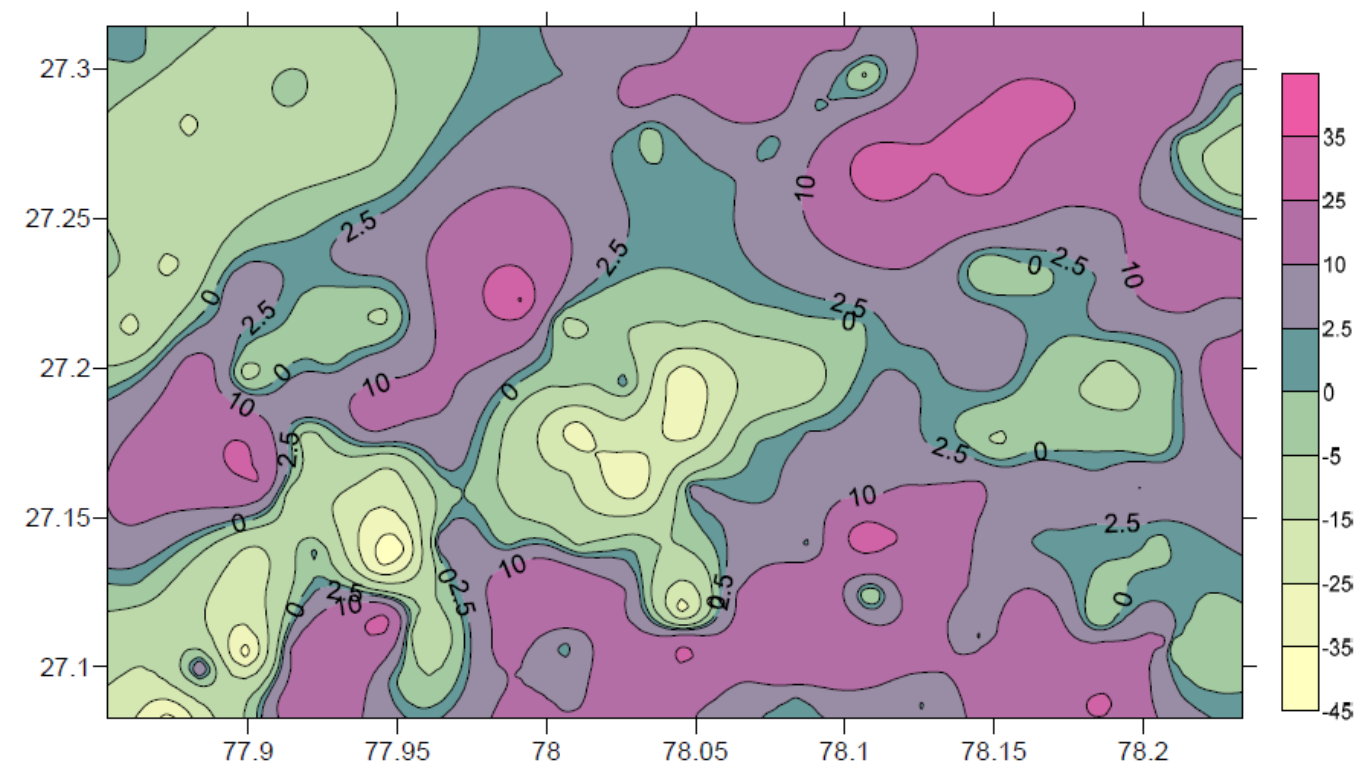

Fig.10: Residual Sodium Carbonate distribution pattern (Contour values in meq/l).

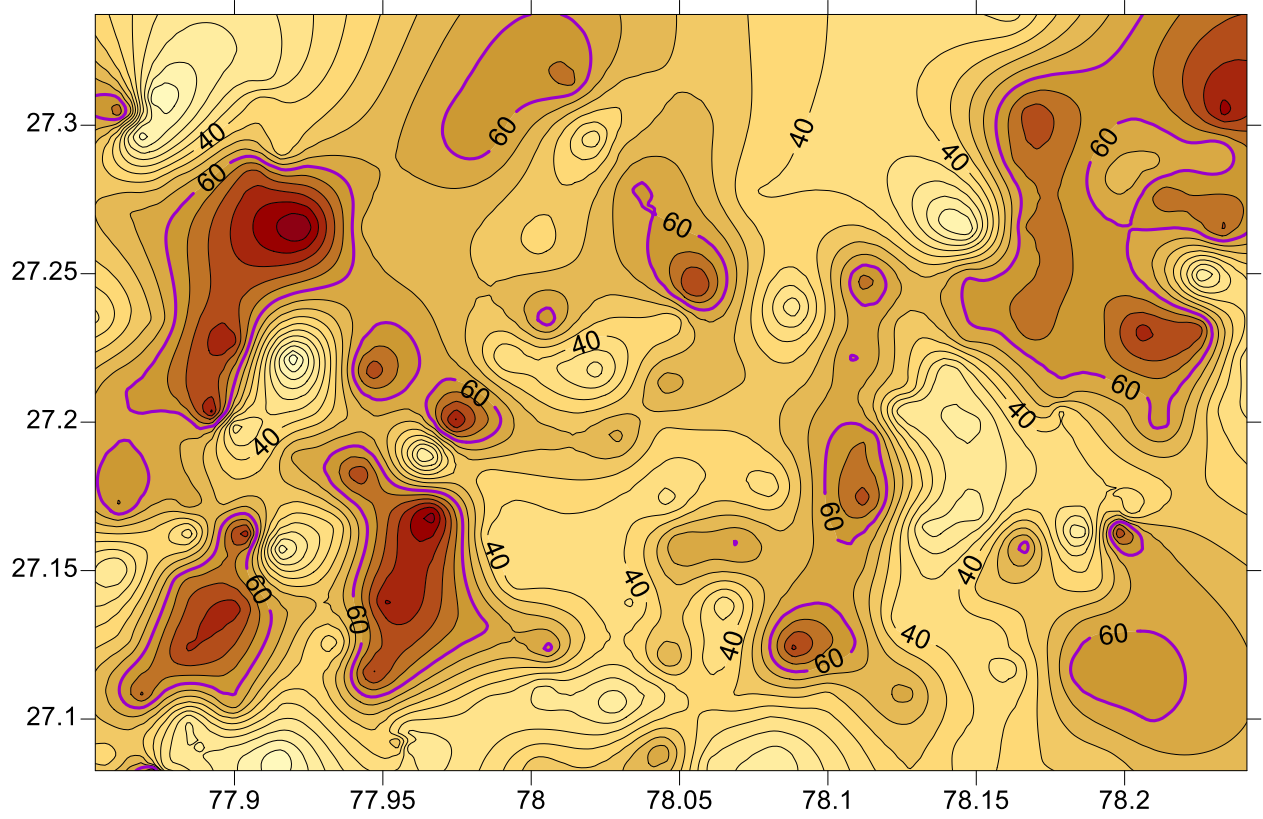

Fig. 11: Water quality on the basis of Sodium percent (water with $\mathrm{Na} \%>60$ is not permissible) 


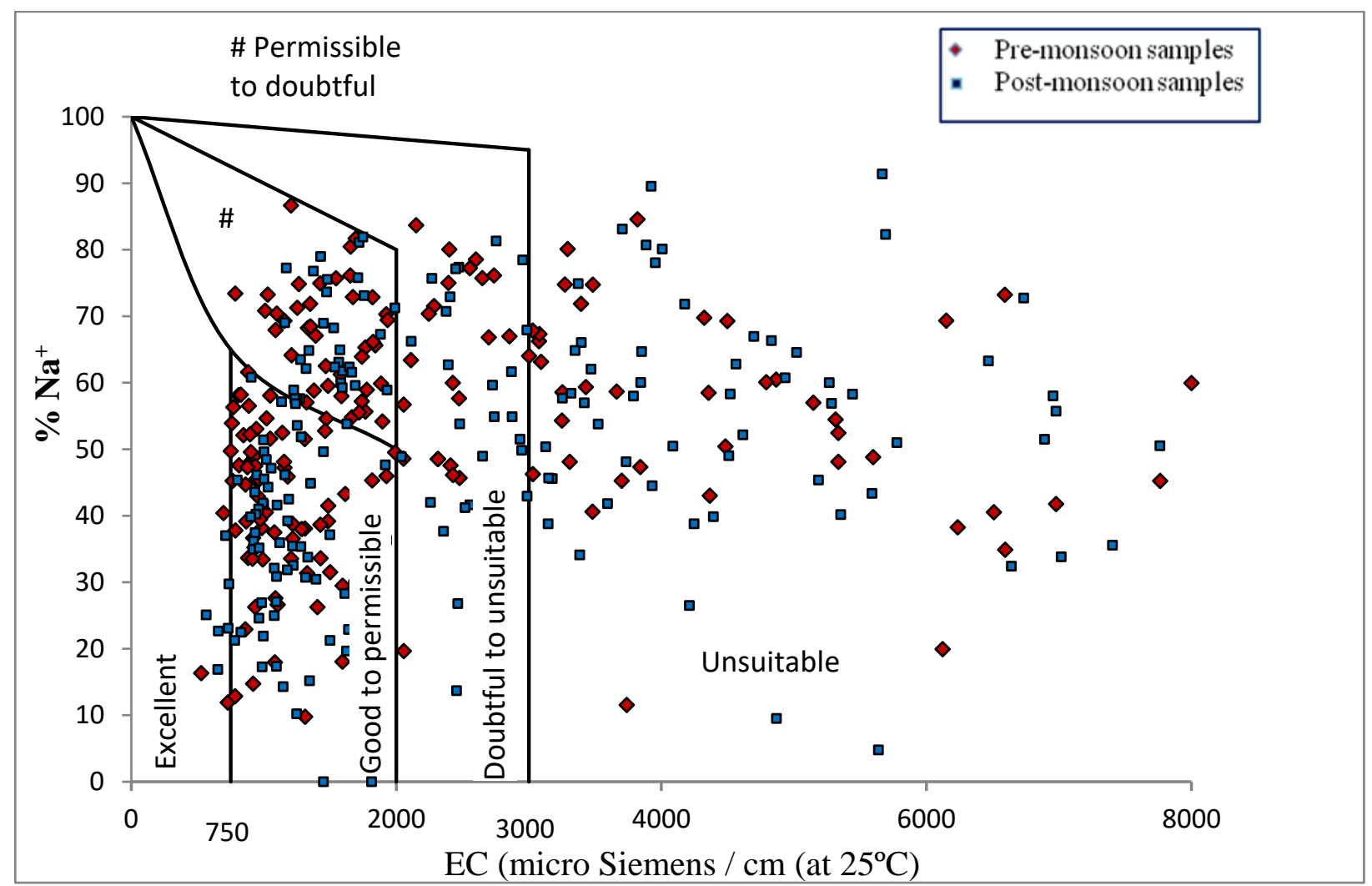

Fig. 12: Wilcox's diagram plot to evaluate the quality of water for irrigation.

Wilcox (1955) classified the water for irrigation taking into account the sodium percent as well as the total ions represented in the form of Electrical Conductance of the water. Wilcox diagram classified most of the water samples into Good-permissible to unsuitable zones as shown in the Fig. 12. About 18\% samples fall in the Unsuitable class, $14 \%$ samples in Doubtful to Unsuitable class, $21 \%$ samples under class Permissible to doubtful and $47 \%$ samples fall in the class Good to permissible including excellent.

\section{Sodium Adsorption Ratio and USSL Classification:}

This parameter is considered as one of the most important and widespread for classifications of the water for irrigation purpose (Kumarasen and Riyazuddin, 2006). As per US Salinity Lab, SAR predicts the quality of water for irrigation reasonably the well on the basis of cation-exchange reaction quality of the soil due to use of the water. Sodium Adsorption Ratio is calculated by the following equation (Richards, 1954):

$\mathrm{Na}$

$\mathrm{SAR}=$

$\sqrt{ }[(\mathrm{Ca}+\mathrm{Mg}) / 2] \quad$ (All ionic constituents in $\mathrm{meq} / \mathrm{l})$

This parameter gives the amount of sodium in water with respect to the calcium and magnesium, therefore measuring the possible sodium hazard to the soil. In this diagram Alkali 
Assessment of Shallow Groundwater Quality for Irrigation in parts of Agra District, Uttar Pradesh (India): Singh et al.

hazard in the form of Sodium Adsorption Ratio and salinity hazard, measured in the form of Electrical Conductivity (in micro $\mathrm{mho} / \mathrm{cm}$ at $25^{\circ} \mathrm{C}$ ) is considered for determining the quality of the groundwater.

Salinty Hazard, EC (mmho/cm at $25^{\circ} \mathrm{C}$ )

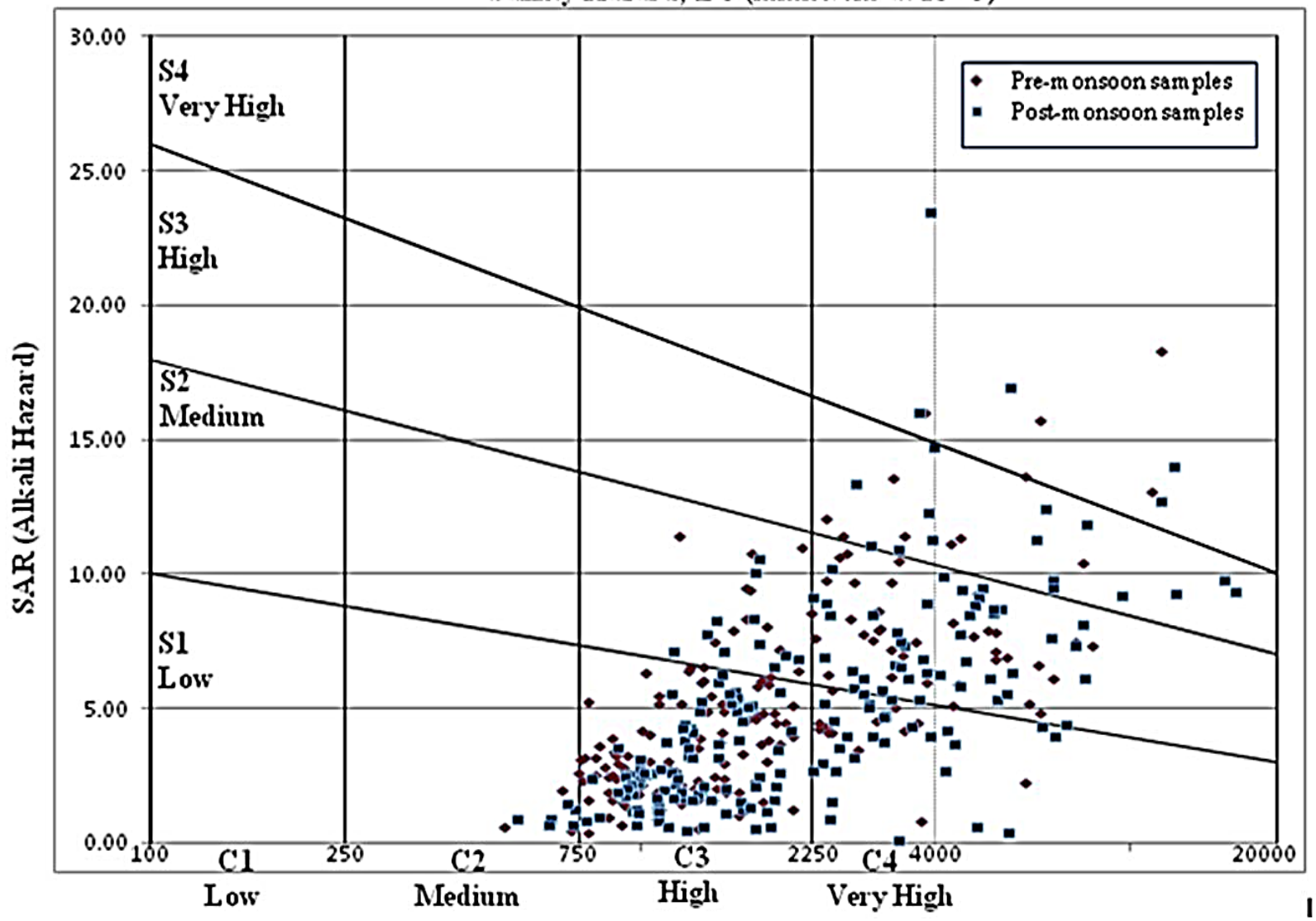

Fig.13: USSL diagram for evaluating groundwater for irrigation.

The exercise indicates that almost all the groundwater samples from Agra area are falling in the S1C3 (50.5\%), S2C3 (6.3\%), S1C4 (10.5\%), S2C4 (20.3\%) and S3C4 (7.6\%) zones of the plot (Fig. 13). Only $2.3 \%$ of samples are falling in S1C2 class with low alkali and medium salinity hazard whereas the same amount of samples fall in S4C4, very high alkali and salinity hazard field. It shows that, in general, all the samples are in the High to Very High salinity zone. Therefore, this water cannot be used on soil with restricted drainage. Even with adequate drainage, without special management for salinity treatment, the water will be harmful to the soil. The water with very high salinity (S4C4 zone) is not suitable for irrigation under ordinary conditions (Karanth, 1987). The Medium alkali water (S2) represents an appreciable sodium hazard in the fine-textured soil of Older Alluvium which is having high cation exchange capacity, especially under low leaching conditions. This water may be used for irrigation only in coarse-textured soil with good permeability. The high sodium water (S3) may produce the harmful level of sodium hazard in normal condition hence avoided. The High to Very high salinity combined with low to medium Alkali hazard makes most of the underground water sources unsuitable for irrigation in the area without special measures. Application of gypsum or other amendments may make the use of these waters feasible (Karanth, 1987). The high salinity combined with sodium hazard may be 

et al.

responsible for the development of alkaline soil (usher) in the area around Khairagarh area, to the south-west of the Agra city (Fig.14).

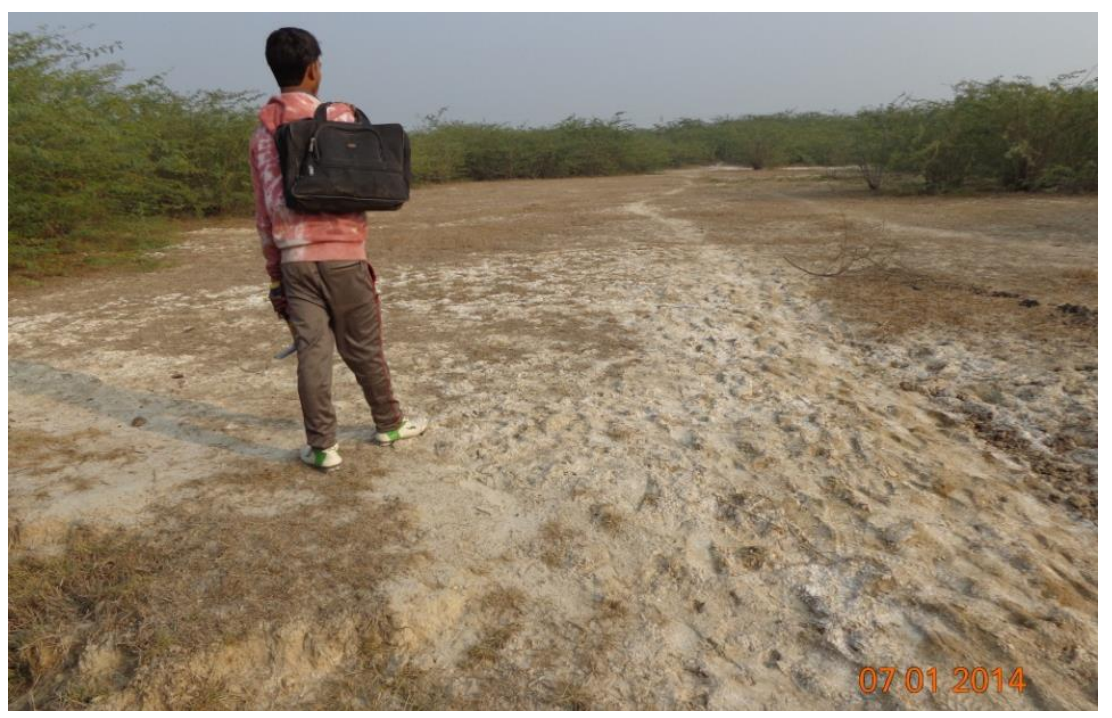

Fig.14: Alkaline soil to the south-west of Agra (Khairagarh).

\section{CONCLUSION}

In this study assessment of groundwater of the area around Agra city has been done considering all the important parameters utilized for evaluating the water for irrigational use. Since the area falls in the semiarid climatic zone and intensively cropped using mainly groundwaters sources of irrigation, it is very important to evaluate the groundwater quality for irrigation so that adequate measures may be planned for healthy and sustainable agricultural practices. On the basis of various parameters, it is found that the groundwater in major part of the area is not good for irrigation. A number of groundwater sources are extremely unsuitable for the use. Sodium content in the water is very high on average. Wicox diagram indicates $18 \%$ of the samples are unsuitable while $14 \%$ samples are doubtful to unsuitable. USSL diagram indicate that $50.5 \%$ ) of the samples fall in S1C3 and $20.3 \%$ in S2C4 field and only $2.3 \%$ samples are falling in S1C2 class with low alkali and medium salinity hazard. The Magnesium content in the water is also very high. Magnesium Adsorption Ration of the water samples is beyond permissible limits for more than $90 \%$ samples. Donnen's plot indicates that $39.3 \%$ of water samples are falling in Class-III field with $<25 \%$ maximum permeability which is not suitable for irrigation in normal conditions. $51 \%$ of samples are showing Kelly's ratio of $>1$, making the water unsuitable for irrigation water without proper corrective measures. Therefore, it is concluded that proper soil and drainage management should be followed in the area for conserving the soil to support long-term productivity. The groundwater sources with extreme results should be avoided and alternative sources of irrigation should be developed. The area is having a good network of canals fed by the rivers which may be revived in the area for irrigation. Proper cropping pattern should be followed for sustainable agricultural development in the area.

Acknowledgment: The authors express their sincere thanks to the Director General, GSI, Dy. Director General and HoD, GSI, NR and RMH Mission-IV, NR for according permission to publish the paper. The data for the study were collected as a part of FS 2012-13 and 13-14 of the Project Environmental Geology 
Assessment of Shallow Groundwater Quality for Irrigation in parts of Agra District, Uttar Pradesh (India): Singh et al.

of SU: UP, NR. The entire concerned, especially Shri R.P.Rai is duly acknowledged. Dr. Alok Kumar helped in data plotting. The officers of Chemical lab of GSI, NR deserve special thanks for analyzing water samples.

\section{REFERENCES}

Ayers, R.S. and Bronson, R.L. (1975) Guidelines for interpretation of water quality for Agriculture University of California, Extension Mime- ographed, $13 \mathrm{p}$.

BIS (1991) Indian standards specifications for drinking water. Bureau of Indian Standards, New Delhi. IS: 10500.

Chandu, S.N., Subbarao, N.V. and Prakash, S.R. (1995) Suitability of groundwater for domestic and irrigational purposes in some parts of Jhansi District, U.P. Bhujal News, v. 10(1), pp. 12-17.

Domenico, P. A. and Schwartz, F. W. (1990) Physical and chemical hydrogeology (2nd edn) Wiley, New York, 528.

Doneen, L.D. (1961) Notes on water quality in Agriculture. Published as a Water Science and Engineering Paper 4001, Department of Water Sciences and Engineering. University of California.

Domenico, P.A. and Schwartz, F.W. (1990) Physical and Chemical Hydrogeology. John Wiley \& Sons, New York, $824 \mathrm{p}$.

Eaton, F. M. (1950) Significance of carbonates in irrigation waters. Soil. Sci., v.69, pp.123-133.

Gupta, S.K. and Gupta, I.C. (1987) Management of saline soils and water. Oxford and IBH Publication Coy, New Delhi, India, 399 p.

Joshi, D.M., Kumar, A. and Agrawal, N. (2009) Assessment of the irrigation water quality of River Ganga in Haridwar district India. J. Chem., v. 2(2), pp. 285-292.

Karanth, K. K. (1987) Ground water assessment, development and management. Tata McGraw-Hill Education, 720p.

Kelley, W.P., Brown, S.M. and Leibig, G.I. Jr. (1940) Chemical effects of saline Irrigation water on soils. Soil Science, v. 49, pp. 95-107.

Kelly, W. P. (1951) Alkali soils-their formation properties and reclamation. 3rd edition. Reinhold Publication, New York, USA, $92 \mathrm{p}$.

Kelly, W.P. (1963) Use of saline irrigation water. Soil Sci., v. 95(4), pp. 355-391.

Khan, T.A., Abbasi, A.M., Khan, A.K. (2013) Synthesis of parameters used to check the suitability of water for irrigation purposes, Inter. Jour. Environmental Sciences, v. 3-6, pp. 2031-2038.

Kumaresan, M. and Riyazuddin, P. (2006) Major ion chemistry of environmental samples around sub-urban of Chennai city. Curr. Sci., v.91(12), pp.1668-1677.

MichaeL, A.M. (1990) Irrigation: theory and practice. Vikas Publishing House Pvt. Ltd., New Delhi, 801p.

Ministry of Agriculture, Gol (2013) Website: www.agricoop.nic.in.

Obiefuna, G.I. and Sheriff, A. (2011) Assessment of Shallow Ground Water Quality of Pindiga Area, Yola Area, NE, Nigeria for Irrigation and Domestic Purposes. Res. Jour. Environmental and Earth Sciences, v.3 (2), pp.131-141.

Quddus, K.G. and Zaman, M.W. (1996) Irrigation water quality in some selected villages of Meherpur in Bangladesh. J. Agric. Sci., v. 23(1), pp. 51-57.

Raghunath, I.M. (1987) Groundwater. 2nd Edn., Wiley Eastern Ltd., New Delhi, India.

Rai, J.N. (1996) Study of impact of groundwater utilization for urban water supply to Agra city and future prospect, Central Ground Water Board, NR, Report: 59.

Raihan, F. and Alam, J.B. (2008) Assessment of groundwater quality in sunamganj Bangladesh Iranian. J. Environ. Health Sci. Eng., v. 6(3), pp.155-166.

Richards, L. A. (1954) Diagnosis and improvement of saline and alkali soils, Agricultural Handbook 60, U.S. Dept. Agric., Washington, D.C., 160p.

Sarkar, A. A. and Hassan, A. A. (2006) Water quality assessment of a groundwater basin in Bangladesh for irrigation use. Pak. J. Biol. Sci., v.9(9), pp.1677-1684.

Singh, P. K. and Atal, S. (2014) Groundwater contamination studies of shallow aquifer in parts of urban and suburban areas of Agra, U.P. Unpub. Report Geol. Surv. Ind., FS.2012-14. 
Assessment of shallow groundwater quality for irrigation in parts of Agra District, Uttar Pradesh, India: Singh et al.

Talukder, M.S.U., Shirazi, S.M. and Paul, U.K. (1998) Suitability of groundwater for irrigation at Kirimganj Upazila Kishoreganj. Progress Agric., v.9, pp.107-112.

Todd, D.K. (1995) Groundwater hydrology. 3rd Edn., Wiley and Sons Inc., New York, U.S., 625p.

Wilcox, L.V. (1955) Classification and use of irrigation waters. US Department of Agriculture, Arc 969, Washington DC, 28p.

(Received: 19.04.2018; Accepted: 25.06.2018) 